\title{
Prevalencia de la translocación robertsoniana 1;29 bovina en hatos ganaderos del estado de Zacatecas, México
}

\section{Prevalence of the Robertsonian (1;29) translocation in cattle in the state of Zacatecas, Mexico}

\author{
Carlos Meza-Lópeza, Braulio Lozano-Carbajala, Federico de la Colina-Floresa, Rómulo \\ Bañuelos-Valenzuelaa, Marco Antonio López-Carlosa, Francisco G. Echavarría-Cháirezb, \\ Luis Roberto Reveles-Torres ${ }^{b}$
}

\begin{abstract}
RESUMEN
El objetivo del trabajo fue determinar la prevalencia de la Translocación robertsoniana 1;29 (t rob 1;29) en hatos ganaderos del estado de Zacatecas, México. Se obtuvieron muestras sanguíneas de 661 bovinos de las razas Holstein $(n=284)$, Suizo Americano $(n=213)$, Suizo Europeo $(n=69)$, Simmental $(n=13)$, Angus $(n=5), C r i o l l o(n=65)$, Chianina $(n=3)$ y Charolais $(n=9)$. Los muestreos se realizaron en nueve municipios de Zacatecas y uno de Agusacalientes. Se registró además la edad, el sexo y el propósito productivo. La identificación de la t rob 1;29 se realizó mediante técnica convencional de citogenética. Se observó una prevalencia general del $4.1 \%$, sin diferencias ( $P>0.05)$ entre machos y hembras $(6.0$ vs $3.4 \%$ respectivamente), aunque superior $(P<0.10)$ en animales jóvenes vs adultos (5.4 vs $2.6 \%$ respectivamente). Se observaron diferencias raciales $(P<0.001)$, con una mayor prevalencia en la raza Criollo (12.3\%), seguida de la raza Suizo Americano (7.5 \%) y menor entre las razas Suizo Europeo $(1.4 \%)$, Holstein $(0.4 \%)$ y otras $(0.0 \%)$. De acuerdo al propósito productivo se encontró una mayor prevalencia $(P<0.001)$ en las explotaciones de doble propósito $(12.3 \%)$ que en los dedicadas exclusivamente a la producción de leche $(3.3 \%)$ o carne $(2.4 \%)$. Con base en estos resultados y debido a los potenciales efectos negativos sobre la productividad del hato, es recomendable el análisis cromosómico de los animales reproductores como práctica rutinaria de identificación de animales portadores de la t rob 1;29, principalmente en los sementales.
\end{abstract}

PALABRAS CLAVE: Ganado bovino, Translocación robertsoniana 1;29, Aberración cromosómica.

\begin{abstract}
The purpose of this work was to estimate the prevalence of the Translocation $1 ; 29$ ( $t$ rob $1 ; 29$ ) in cattle herds in the Mexican state of Zacatecas. Blood samples were obtained from 661 bovines of eight breeds: Holstein ( $n=284$ ), American Swiss $(n=213)$, Braunvieh $(n=69)$, Simmental $(n=13)$, Angus $(n=5)$, Creole $(n=65)$, Chianina $(n=3)$ and Charolais $(n=9)$. Sampling was conducted in nine municipalities of the state of Zacatecas and one in the state of Aguascalientes. Age, sex and productive purpose were also recorded. Identification of the t rob 1;29 was performed by conventional cytogenetic technique. An overall prevalence of $4.1 \%$, with no differences between males and females (6.0 vs $3.4 \%$ respectively), although greater $(P<0.10)$ in young animals vs adults $(5.4$ vs $2.6 \%$ respectively) was observed. Breed differences $(P<0.001)$ were observed with a greater prevalence in the Criollo breed $(12.3 \%)$, followed by Swiss American breed $(7.5 \%)$ and lower among Braunvieh $(1.4 \%)$, Holstein $(0.4 \%)$ and others breeds $(0.0 \%)$. According to productive purpose a greater prevalence $(P<0.001)$ was observed in dual purpose farms $(12.3 \%)$ than dedicated exclusively to the milk $(3.3 \%)$ or beef $(2.4 \%)$ production. Based on these results and because of the potential negative effects on herd productivity, a chromosomal analysis of breeding animals is recommended as a routine practice, to identify animals carrying the $t$ rob $1 ; 29$, mainly in sires.
\end{abstract}

KEY WORDS: Cattle, Translocation 1;29, Chromosomal aberration.

Recibido el 14 de agosto de 2014. Aceptado el 24 de noviembre de 2014.

a Universidad Autónoma de Zacatecas, Unidad Académica de Medicina Veterinaria y Zootecnia, Carretera Panamericana Zacatecas Fresnillo Km 31.5. El Cordovel, Gral. Enrique Estrada, Zacatecas. 98500. México.

b Campo Experimental Calera. CIR-Norte Centro. Instituto Nacional de Investigaciones Forestales, Agrícolas y Pecuarias. México. echavarria.francisco@inifap.gob.mx. Correspondencia al sexto autor. 


\section{INTRODUCCIÓN}

En el arreglo cromosómico de los bovinos, el cariotipo está constituido por 29 pares de autosomas acrocéntricos y por un par de cromosomas sexuales, de los cuales el $X$ es submetacéntrico, mientras que el cromosoma $Y$ es submetacéntrico en Bos taurus y acrocéntrico en Bos indicus(1). El número de cromosomas es diploide en la mayoría de las especies de mamíferos, que se caracterizan por un número de cromosomas polimorfos; ocasionalmente la variación de los números diploides de una especie resulta de fusiones centroméricas (translocación robertsoniana), que involucra a dos cromosomas acrocéntricos(2).

El primer informe de alteración cromosómica en la citogenética veterinaria en la que se observa una translocación fue reportada en 1964(3), donde se informó sobre la translocación "Robertsoniana" ahora también conocida como la translocación rob 1;29(4). Esta anomalía cromosómica es la más frecuente reportada en bovinos(1) y ha sido identificada en más de 60 razas de esta especie en todo el mundo, pudiendo ocurrir hasta en un $25 \%$ en poblaciones de ganado bovino productor de carne(5).

Las aberraciones cromosómicas estructurales en ganado bovino, especialmente las balanceadas, son más importantes debido a su alta frecuencia. Por ejemplo, la fusión céntrica o translocación robertsoniana produce individuos fenotípicamente normales en conformación corporal, pero de baja fertilidad en portadoras, las cuales producen gametos con números cromosómicos desequilibrados y embriones que mueren durante la vida embrionaria temprana, lo que incrementa el número de servicios por concepción y el intervalo entre partos(6).

La utilización de un número reducido de sementales a través de inseminación artificial presenta un riesgo considerable para la población, debido a la rápida propagación de defectos genéticos no diagnosticados y

\section{INTRODUCTION}

The karyotype of the bovine chromosomal arrangement consists of 29 acrocentric autosomal pairs and one pair of sexual chromosomes. Of the latter, the $X$ is always submetacentric while the $Y$ is submetacentric in Bos taurus and acrocentric in Bos indicus(1). Chromosome count is diploid in most mammals, which characteristically have a polymorph number of chromosomes. Variation in the number of diploids occasionally causes centromeric fusions, known as Robertsonian translocation, involving two acrocentric chromosomes(2).

In veterinary cytogenetics, the first report of chromosomal alteration involving translocation was published in 1964(3). Originally called Robertsonian translocation, it is now commonly referred to as rob 1;29 translocation(4). Frequently reported in cattle(1), this chromosomal anomaly has been identified in over sixty breeds worldwide, and may occur in up to $25 \%$ of beef cattle populations( 5 ).

Because of their high frequency, structural chromosomal aberrations, particularly balanced ones, are the most important in cattle. For example, centric fusion (i.e. Robertsonian translocation) results in phenotypically normal individuals in terms of body arrangement, but carriers have low fertility. They produce gametes with uneven numbers of gametes and their embryos die in early stages, requiring more services per conception and longer calving intervals(6).

Use of small numbers of sires via artificial insemination poses a substantial risk to cattle populations because undiagnosed genetic defects and chromosomal anomalies can propagate quickly. Sires that are heterozygotic carriers are generally phenotypically normal. However, they manifest varying decreases in fecundity that can result in a significant percentage of anomalous gametes and recurring spontaneous abortions(7). Indeed, fertility can 
anomalías cromosómicas. Los sementales que son portadores heterocigotos generalmente tienen un fenotipo normal, pero muestran disminuciones variables de la fecundidad, que pueden producir un porcentaje significativo de gametos anómalos que conducen a abortos espontáneos recurrentes(7). En este sentido, se ha reportado que las poblaciones afectadas por la t rob 1;29 presentan una disminución de la fertilidad que va de 3 a $25 \%$ en los animales heterocigóticos( $(8)$.

Entre los problemas reproductivos de la t rob 1;29 se encuentran: disminución de la tasa de concepción, aumento del número de servicios por concepción, del intervalo entre partos, del intervalo parto concepción y mortalidad embrionaria(9).

El propósito del trabajo fue determinar la prevalencia de la $t$ rob 1;29 bovina en hatos ganaderos de distintas razas y edades, explotados en distintos sistemas de producción y manejo reproductivo, en nueve municipios del estado de Zacatecas y uno del estado de Aguascalientes, México.

\section{MATERIALES Y MÉTODOS}

Se realizó el análisis cromosómico en 661 bovinos de las razas Holstein $(n=284)$, Suizo Americano $(n=213)$, Suizo Europeo $(n=69)$, Simmental $(n=13)$, Angus $(n=5)$, Criollos $(n=$ $65)$, Chianina $(n=3)$ y Charolais $(n=9)$, ubicados en nueve municipios del estado de Zacatecas (Fresnillo, Gral. Enrique Estrada, Luis Moya, Sombrerete, Tepetongo, Tlaltenango, Valparaiso y Zacatecas) y uno del estado de Aguascalientes (Pabellón de Arteaga), México. De cada individuo se obtuvieron aproximadamente $7 \mathrm{ml}$ de sangre de la vena yugular en tubos vacutainer heparinizados. En el laboratorio se tomaron $0.5 \mathrm{ml}$ de sangre de cada muestra y se colocaron en tubos de cultivo con $3.0 \mathrm{ml}$ de medio McCoy 5 A modificado (Laboratorio Microlab S.A. de C.V.) al que se le agregaron $0.2 \mathrm{ml}$ de fitohemaglutinina, para posteriormente incubarse a $38^{\circ} \mathrm{C}$ por $71 \mathrm{~h}$. Pasado el periodo decrease from 3 to $25 \%$ in heterozygotic animals in cattle populations carrying the rob $1 ; 29(8)$.

Overall, the rob $1 ; 29$ can lead to reproductive problems that affect cattle ranch operating costs and efficiencies, such as lower conception rate, a greater number of services per conception, longer intervals between pregnancies and embryo death(9). The present study objective was to quantify the presence of the rob $1 ; 29$ in cattle of different breeds and ages under different production systems and reproductive management systems in nine municipalities in the state of Zacatecas and one in the state of Aguascalientes, Mexico.

\section{MATERIALS AND METHODS}

Chromosomal analysis was done of 661 individuals from eight cattle breeds: Holstein $(n=284)$, Swiss American $(n=213)$, Swiss European $(n=69)$, Simmental $(n=13)$, Angus $(n=5)$, Criollo $(n=65)$, Chianina $(n=3)$ and Charolais $(n=9)$. Samples were taken at production units in nine municipalities in the state of Zacatecas (Fresnillo, Gral. Enrique Estrada, Luis Moya, Sombrerete, Tepetongo, Tlaltenango, Valparaiso and Zacatecas), and one in the state of Aguascalientes (Pabellón de Arteaga). Blood samples (approx. $7 \mathrm{ml}$ ) were taken from the jugular vein of each animal using heparinized vacutainer tubes. In the laboratory, $0.5 \mathrm{ml}$ was taken from each blood sample, placed in culture tubes containing $3.0 \mathrm{ml}$ modified McCoy 5A medium (Laboratorio Microlab S.A. de C.V.), and $0.2 \mathrm{ml}$ phytohemaglutinine added. After incubation at $38^{\circ} \mathrm{C}$ for $71 \mathrm{~h}, 1.0 \mathrm{ml}$ colchicine $(4 \mu \mathrm{g} / \mathrm{ml}$ in PBS) was added to each tube and they were set aside for $1 \mathrm{~h}$. They were then centrifuged $(3,000 \mathrm{rpm}$ for $10 \mathrm{~min})$, decanted and $6 \mathrm{ml}$ $0.075 \mathrm{M} \mathrm{KCl}$ (i.e. hypotonic solution) added. After $30 \mathrm{~min}$, the tubes were centrifuged and decanted again, followed by fixing with Carnoy's (3:1 methanol:acetic acid solution). Three washes were done with this solution and the 
de incubación, se agregó $1.0 \mathrm{ml}$ de colchicina ( $4 \mu \mathrm{g} / \mathrm{ml}$ en PBS) a cada tubo con muestra y se dejó reposar por $1 \mathrm{~h}$, para posteriormente centrifugar a 3,000 rpm durante $10 \mathrm{~min}$, se decantó y se agregaron $6 \mathrm{ml}$ de $\mathrm{KCl}$ a $0.075 \mathrm{M}$ (solución hipotónica). Pasados 30 min, se volvió a centrifugar y decantar, para luego fijar en una solución de Carnoy metanol-ácido acético en relación $3: 1$. Se realizaron tres lavados con la misma solución, centrifugando y decantando(10,11).

Se procedió a elaborar tres laminillas de cada muestra por goteo. Posteriormente se tiñeron con Giemsa durante $30 \mathrm{~min}$. De éstas, las que presentaron la translocación robertsoniana se bandearon, para lo cual se aplicó tripsina al $0.025 \%$, durante $10 \mathrm{seg}(12)$. Las muestras se montaron con resina, se cuantificaron y analizaron los cromosomas metafásicos observados al microscopio óptico a 10X y 100X. Se obtuvieron las fotografías para realizar los cariogramas correspondientes y llevar a cabo el análisis e identificación de las translocaciones rob $1 ; 29$.

Para el análisis estadístico se utilizó el lenguaje y ambiente de programación estadística $\mathrm{R}$ versión 3.0.3(13). Se analizó la presencia de la translocación de acuerdo al Estado, propósito productivo, raza, sexo y edad. Las relaciones entre variables cualitativas se analizaron mediante pruebas de bondad de ajuste para cuadros de contingencia(14). Se utilizaron los modelos logarítmicos lineales, por ser variables cualitativas, con la función loglm del paquete MASS(15). También se realizaron comparaciones múltiples de proporciones para cuadros de contingencia, con la función "prop.multcomp", del paquete RVAideMemoire(16). El efecto de edad se analizó de dos formas. Primero, dicotomizada en dos grupos etarios: jóvenes (hasta 30 meses de edad) y adultos (mayores a 30 meses de edad), los cuales se analizaron como cuadros de contingencia. Segundo, para ver el efecto de la edad como variable cuantitativa, se realizó un análisis de regresión logística(14). tubes centrifuged and decanted once again $(10,11)$.

Using the drop method, three strips per sample were made, and stained with Giemsa for 30 min. Those that exhibited Robertsonian translocation were flagged with $0.025 \%$ trypsin for $10 \mathrm{sec}(12)$. The strips were mounted in resin and metaphasic chromosomes quantified and analyzed using a microscope at 10X and $100 \mathrm{X}$ magnification. Images were taken to generate the corresponding karyograms for rob $1 ; 29$ analysis and identification.

Statistical analysis was done with the R ver. 3.0.3 programming language and environment(13). Presence of the translocation was analyzed by state, productive purpose, breed, sex and age. Relationships between qualitative variables were analyzed with goodness-of-fit tests for contingency tables(14). Because they were qualitative variables, linear logarithmic models were used by applying the "loglm" function in the MASS program(15). Multiple comparisons of proportions for contingency tables were done with the "prop.multcomp" function of the RVAideMemoire program(16). The effect of age was analyzed in two ways. First, the sample group was divided into young ( $<30 \mathrm{mo})$ and adult (>30 mo) individuals, which were then analyzed as contingency tables. Second, the effect of age as a quantitative variable was analyzed with a logistic regression(14).

\section{RESULTS AND DISCUSSION}

Presence of the rob 1;29 was only identified in animals from the state of Zacatecas (Table 1), but the effect of "state" was not significant $(P=0.479)$ when compared with a Fisher exact test or the likelihood ratio in the linear logarithmic model $(P=0.105)$. This agrees with a study done of rob $1 ; 29$ frequencies in Criollo cattle in Colombia in which no differences in geographic distribution were observed since most sampled animals were in lowland tropical zones(9). 


\section{RESULTADOS Y DISCUSIÓN}

Aunque la translocación rob 1;29 se identificó únicamente en animales procedentes del estado de Zacatecas (Cuadro 1), el efecto de la entidad federativa no fue significativo $(P=0.479)$ al compararlo mediante prueba exacta de Fisher o mediante la razón de verosimilitud en el modelo logarítmico lineal $(P=0.105)$. De acuerdo con los resultados aquí presentados, Sánchez $(9)$ realizó un trabajo en bovinos criollos Colombianos, reportando que no encontraron diferencias en cuanto a la distribución geográfica, ya que la mayoría de estos bovinos se encuentra en zonas de trópico cálido bajo.

La prevalencia de la t rob $1 ; 29$ de acuerdo al sexo de los animales (Cuadro 1$)$, no fue diferente $(P=0.258)$ al realizar pruebas de bondad de ajuste para tablas de contingencia, ni para la razón de verosimilitud en el modelo logarítmico lineal $(P=0.190)$. Otros autores(17) que trabajaron con la t rob 1;29 en bovinos criollos y mestizos venezolanos, reportaron una prevalencia del $20 \%$ en machos, $8 \%$ de hembras heterocigóticas y $2 \%$ de hembras homocigóticas.

En cuanto al grupo etario (Cuadro 1) la razón de verosimilitud en el modelo logarítmico lineal mostró una $P=0.058$. La diferencia entre la proporción de animales jóvenes afectados por la $t$ rob 1;29 menos la de los adultos fue de 0.0286 , con un intervalo de confianza de $95 \%$ que va de -0.0016 a 0.0588 . Además, los animales jóvenes presentaron 2.17 veces mayor riesgo de presentar la translocación rob 1;29, con un intervalo de confianza que va de 0.95 a 4.94 .

Cuando se consideró a la edad como una variable cuantitativa, la regresión logística rindió una intersección de $-2.66 \pm 0.27$, significativamente diferente de cero $(P<0.001)$, $y$ una pendiente de $-0.180 \pm 0.076$, significativamente diferente de cero $(P=0.018)$. Esto nos reporta una razón de momios igual a
Neither the goodness-of-fit tests for contingency tables nor the likelihood ratio in the linear logarithmic model $(P=0.190)$ identified differences $(P=0.258)$ in rob $1 ; 29$ prevalence by animal sex (Table 1$)$. This differs from a previous study in which rob $1 ; 29$ prevalence in Criollo and Mestizo cattle in Venezuela was $20 \%$ in males, $8 \%$ in heterozygotic females and $2 \%$ in homozygotic females(17).

For age group (Table 1), the likelihood ratio had $P=0.058$ and the difference between young and adult carrier animals was 0.0286 (95\% confidence interval $=-0.0019$ to 0.0588 ). Young animals were also at a 2.17 times greater risk for carrying rob $1 ; 29$ (interval $=0.95$ to 4.94 ).

When age was treated as a quantitative variable, the logistical regression produced an intersection of $-2.66 \pm 0.27$, which differed from zero $(P<0.001)$, and a slope of $-0.180 \pm$ 0.076 , again, different from zero $(P=0.018)$. This results in an odds ratio of 0.836 , meaning the probability of choosing an animal with the translocation decreases $16.4 \%$.

Practically all cattle breeds worldwide are affected by the rob $1 ; 29$ translocation, and they manifest

Cuadro 1. Prevalencia de la t rob 1;29 bovina en hatos ganaderos por entidad federativa, sexo y grupo etario (\%) Table 1. Prevalence of rob $1 ; 29$ translocation in cattle by state, sex and age group (\%)

\begin{tabular}{lccc}
\hline & \multicolumn{2}{c}{ rob $1 ; 29$} & \\
\cline { 2 - 3 } & No & Yes & Total \\
\hline State: & & & \\
Zacatecas $(n=629)$ & 95.9 & $4.1^{\mathrm{a}}$ & 100.0 \\
Aguascalientes $(\mathrm{n}=32)$ & 100.0 & $0.0^{\mathrm{a}}$ & 100.0 \\
Sex: & & & \\
Female $(\mathrm{n}=528)$ & 96.6 & $3.4^{\mathrm{a}}$ & 100.0 \\
Male $(\mathrm{n}=133)$ & 94.0 & $6.0^{\mathrm{a}}$ & 100.0 \\
Age group: & & & \\
Young $(n=312)$ & 94.6 & $5.4^{\mathrm{a}}$ & 100.0 \\
Adult $(n=349)$ & 97.4 & $2.6^{\mathrm{b}}$ & 100.0 \\
\hline
\end{tabular}

Young ( $<30 \mathrm{mo}$ of age); adults ( $>30 \mathrm{mo}$ of age).

ab Different letter superscripts in the same column indicate significant difference $(P<0.10)$. 
0.836 , lo que significa que la probabilidad de que se seleccione un bovino con la translocación disminuye un $16.4 \%$.

La t rob 1;29 es de distribución mundial y afecta prácticamente todas las razas de ganado vacuno y es causante de una disminución de la fertilidad(18). En el presente trabajo se observó una mayor proporción de esta aberración en animales jóvenes (menores de 30 meses) que en animales adultos, lo que posiblemente se debe a que las hembras adultas son eliminadas al no quedar gestantes, lo cual en algunos casos es atribuible a esta aberración, además de que no es redituable en términos productivos, ya que se dejan de obtener litros de leche o kilogramos de carne y becerras para la reposición.

En países como Estados Unidos y Francia, el análisis de cariotipos se utiliza con mayor frecuencia en la detección de animales portadores como apoyo a los procedimientos de selección de sementales y hembras reproductoras(4). En países como México, esto se hace a través de la observación de la progenie, lo cual conlleva varios años y se eliminan sementales de baja fertilidad tardíamente, cuando ya han dejado descendencia.

En el Cuadro 2 se muestra el efecto de la raza sobre la prevalencia de la $\mathrm{t}$ rob 1;29. Se observaron diferencias por efecto de raza al analizarlas mediante el modelo logarítmico lineal $(P<0.001)$. La prueba de proporciones múltiples resultó significativa con una mayor prevalencia en la raza Criollo (12.3\%), seguida de la raza Suizo Americano $(7.5 \%)$ y menor entre las razas Suizo Europeo $(1.4 \%)$, Holstein $(0.4 \%)$ y otras $(0.0 \%)$. La diferencia entre la proporción de animales criollos afectados menos la de las demás razas fue de 0.0929 , con un intervalo de confianza de $95 \%$ que va de 0.0118 a 0.1740 . La razón de momios de que los criollos presenten la translocación fue igual a 4.51 veces más que los otros, con un intervalo de confianza que va de 1.88 a 10.80 . diminished fertility as a consequence(18). Young animals $(<30 \mathrm{mo})$ in the present study most frequently exhibited this aberration. One possible reason is that adult females would be eliminated from a population after presenting difficulty in conception, in some cases due to this translocation. In addition, these females would cease to be profitable in productive terms since they would no longer produce the liters of milk, kilograms of meat or calves required of them.

Karyotype analysis is commonly used in countries such as the United States and France to identify rob $1 ; 29$ carriers as part of the sire and dam selection process(4). In developing countries such as Mexico, this process is done by observing progeny, a process that can take many years. Even when low fertility sires are removed from the population, it is not until after they have contributed to the gene pool.

Breed had a clear effect $(P<0.001)$ on rob $1 ; 29$ prevalence as determined by the linear logarithmic model (Table 2). The multiple proportions test was significant with the highest prevalence in the Criollo breed $(12.3 \%)$, followed by Swiss American (7.5 \%), Swiss European (1.4\%), Holstein (0.4\%) and Others

Cuadro 2. Efecto de la raza sobre la prevalencia de la $t$ rob 1;29 bovina en hatos ganaderos del estado de Zacatecas, México (\%)

Table 2. Effect of breed on rob 1;29 prevalence in cattle herds in the state of Zacatecas, Mexico (\%)

\begin{tabular}{|c|c|c|c|}
\hline \multirow[b]{2}{*}{ Breed } & \multicolumn{2}{|c|}{ rob 1;29 } & \multirow[b]{2}{*}{ Total } \\
\hline & No & Yes & \\
\hline Holstein $(n=284)$ & 99.6 & $0.4^{a}$ & 100.0 \\
\hline Swiss American $(n=213)$ & 92.5 & $7.5 \mathrm{~b}$ & 100.0 \\
\hline Swiss European $(n=69)$ & 98.6 & $1.4^{\mathrm{a}}$ & 100.0 \\
\hline Criollo $(n=65)$ & 87.7 & $12.3^{c}$ & 100.0 \\
\hline Others $(n=30)^{1}$ & 100.0 & $0.0^{a}$ & 100.0 \\
\hline
\end{tabular}

1 Simmental $(n=13)$, Angus $(n=5)$, Chianina $(n=3)$ and Charolais $(n=9)$.

abc $(P<0.001)$. 
La presencia de la translocación $r$ 1;29 en los hatos bovinos afecta los parámetros reproductivos, ya que se presenta una alta mortalidad embrionaria durante los primeros cinco días de desarrollo, debido a monosomía o trisomía de los cromosomas 1 ó 29. Algunos fetos trisómicos continúan su desarrollo hasta el primer trimestre de gestación y luego son abortados(11). La mayor incidencia en el ganado explotado en condiciones extensivas, se debe a la introducción de sementales jóvenes que no han sido previamente evaluados y al intercambio que se hace de sementales entre hatos sin un análisis cromosómico previo.

En este estudio, la prevalencia de la de la t rob $1 ; 29$ fue mayor en el ganado de la raza Suizo Americano ( $7.5 \%$ ) que en otras razas puras, lo que coincide con los valores de prevalencia de $10.37 \%(19)$ y $7.14 \%(1)$ reportados para poblaciones de esta raza en los Estados Unidos de Norteamérica.

En el Cuadro 3 se muestra la prevalencia de la t rob 1:29 de acuerdo al propósito productivo de la explotación. La prueba de bondad de ajuste arrojó una $P=0.001$, mientras que la razón de verosimilitud en el modelo logarítmico lineal mostró una $P<0.001$. La prueba de proporciones múltiples mostró que la prevalencia de esta anormalidad es mayor $(P<0.001)$ en los sistemas de producción de doble propósito (12.3\%) que en los sistemas dedicados exclusivamente a la producción de leche (3.3\%) o carne (2.4\%). La razón de momios de que el ganado de doble propósito presente la translocación robertsoniana fue 4.15 veces más que en el ganado lechero (intervalo de confianza de 1.67 a 10.30) y 5.75 veces más que el ganado de carne (intervalo de confianza de 1.67 a 19.8).

En el Cuadro 4 se muestra la prevalencia de la translocación por municipio del estado de Zacatecas. La prevalencia fue mayor $(P<0.001)$ en Zacatecas y Valparaíso que en el resto de los municipios.

De acuerdo a los resultados presentados, se observó que la raza más afectada fue el ganado
$(0.0 \%)$. The difference between the number of carrier Criollo animals minus the affected individuals from all the other breeds was 0.0929 (interval $=0.0118$ to 0.1740 ). The odds ratio for carrier Criollo individuals was 4.51 times higher than for carriers from the other breeds (interval= 1.88 to 10.80 ).

Presence of rob $1 ; 29$ in cattle herds negatively affects reproductive parameters by producing high embryo mortality during the first $5 \mathrm{~d}$ of development due to monosomy or trisomy of chromosomes 1 to 29. Some trisomic embryos continue developing until the third trimester and then abort(11). The higher rob 1;29 incidence in cattle in extensive systems is caused by introduction of young, unevaluated sires and exchange of sires between herds without previous chromosomal analysis.

Of the pure breeds, rob 1;29 was most prevalent in the Swiss American breed (7.5\%). This coincides with prevalences of $10.37 \%(19)$ and $7.14 \%(1)$ reported for Swiss American populations in the United States.

Analyses of rob $1 ; 29$ prevalence by productive purpose with the multiple proportions test showed a higher $(P<0.001)$ prevalence in double-purpose systems $(12.3 \%)$ than in exclusively dairy $(3.3 \%)$ or beef systems $(2.4 \%)$ (Table 3). In this analysis, the goodness-of-fit

Cuadro 3. Prevalencia de la t rob $1 ; 29$ bovina de acuerdo al propósito productivo en hatos ganaderos del estado de Zacatecas, México (\%)

Table 3. Effect of production system purposes on rob $1 ; 29$ prevalence in cattle herds in the state of Zacatecas, Mexico (\%)

\begin{tabular}{|c|c|c|c|}
\hline \multirow[b]{2}{*}{ Productive purpose } & \multicolumn{2}{|c|}{ rob $1 ; 29$} & \multirow[b]{2}{*}{ Total } \\
\hline & No & Yes & \\
\hline Dairy $(n=428)$ & 96.7 & $3.3^{a}$ & 100.0 \\
\hline Beef $(n=168)$ & 97.6 & $2.4^{\mathrm{a}}$ & 100.0 \\
\hline Double-purpose $(n=65)$ & 87.7 & $12.3^{b}$ & 100.0 \\
\hline
\end{tabular}

ab $(P<0.001)$. 
Criollo de doble propósito y principalmente los animales jóvenes. Resultados similares se reportaron en un estudio realizado en Colombia(8) para evaluar la prevalencia de la translocación en 3 de 7 razas criollas Colombianas, encontrándose una prevalencia de $7.9 \%$ en lo general, y de $12.3 \%$ para la raza Criolla. En otro estudio(20) se reportó una frecuencia de $13.6 \%$ en la raza criolla de doble propósito Chino Santandereano. Esta coincidencia de características (doble propósito y raza criolla) permite ver que es en estos sistemas de producción, que generalmente se caracterizan por su menor manejo tecnológico y sin registros productivos, donde se hace una menor selección del ganado al no contar con elementos que permitan tomar la decisión, lo que incrementa la prevalencia de aberraciones como las aquí reportadas.

En los sistemas de producción intensiva, los animales portadores de la translocación, se pueden detectar fácilmente a través del registro y análisis permanente de sus parámetros productivos y reproductivos, por lo que su presencia puede ser minimizada(8). Por el contrario, en explotaciones de tipo extensivo, donde un número reducido de sementales se mantiene en monta natural con un grupo relativamente grande de vacas y no se tienen registros productivos y reproductivos apropiados, se incrementa la probabilidad de que la anomalía se perpetúe en la población, siendo este último el sistema implementado en la mayoría de grupos de animales criollos colombianos(20). Algo similar ocurre en muchos hatos existentes en los municipios de Zacatecas, donde el ganado pastorea libremente en los agostaderos y se carece de registros productivos(21). De acuerdo con el INEGI(22) el $39 \%$ de los vientres de bovinos del estado de Zacatecas son de doble propósito; el $67 \%$ de los bovinos en general tienen una edad entre 1 y 3 años y la mayor población se ubica en el Municipio de Valparaíso, Zacatecas, por lo que estas tres categorías, propósito productivo, edad y existencias por Municipio, representan la mayor probabilidad de prevalencia de la translocación robertsoniana, test resulted in $P=0.001$ while the likelihood ratio in the linear logarithmic model resulted in a $P<0.001$. The odds ratios for cattle in doublepurpose systems showed them to manifest this translocation 4.15 times more frequently than dairy cattle (interval= 1.67 to 10.30 ) and 5.75 times more frequently than beef cattle (interval= 1.67 to 19.8$)$.

Amongst the municipalities, prevalence was higher $(P<0.001)$ in Zacatecas and Valparaíso than in the other affected municipalities (Table 4).

Of the studied individuals, double-purpose Criollo breed cattle were most affected by the rob $1 ; 29$, particularly young animals. This is comparable to the $7.9 \%$ general prevalence and $12.3 \%$ prevalence for the Criollo breed found in an evaluation of translocation in three of seven Colombian Criollo breeds(8). In another study, prevalence was reported at $13.6 \%$ in Chino Santandereano Criollo breed animals in a double-purpose system(20). This coincidence in characteristics (double-purpose, Criollo breed) suggests that these production systems are more prone to carrying this translocation. They are less mechanized, normally do not keep detailed records, use only basic selection criteria for genetic improvement, and therefore experience higher rob $1 ; 29$ prevalences.

Cuadro 4. Prevalencia (\%) en los municipios del estado de Zacatecas donde se identificó la t rob 1;29

Table 4. Prevalence (\%) of rob 1;29 in municipalities of the state Zacatecas where this translocation was identified

\begin{tabular}{lrrr}
\hline & \multicolumn{3}{c}{ rob $1 ; 29$} \\
\cline { 2 - 3 } Municipalities & No & \multicolumn{1}{c}{ Yes } & Total \\
\hline CVR $(n=144)$ & 99.3 & 0.7 a & 100.0 \\
Luis Moya $(n=41)$ & 97.5 & 2.5 a & 100.0 \\
Valparaiso $(n=194)$ & 92.0 & $8.0 \mathrm{~b}$ & 100.0 \\
Zacatecas $(n=75)$ & 84.6 & $15.4 \mathrm{~b}$ & 100.0 \\
Others $(5)(n=200)$ & 100.0 & 0.0 a & 100.0 \\
\hline
\end{tabular}

$\mathrm{CVR}=$ Calera de Víctor Rosales ab $(P<0.001)$. 
por ser las categorías más abundantes. Lo anterior implica una generalización de su presencia en el Estado, que está asociada a un reducido manejo tecnológico y de registros en los hatos, lo que complica su identificación, ya que además la presencia de la anomalía no se evidencia fenotípicamente en los individuos portadores. La implementación del diagnóstico temprano con pruebas cariotípicas a sementales, además de la realización rutinaria en hembras, permitirá contar con la información para descartar animales afectados y reducir su impacto sobre los indicadores productivos y reproductivos en los hatos ganaderos.

\section{CONCLUSIONES E IMPLICACIONES}

La translocación robertsoniana 1;29 presenta una prevalencia de $4.1 \%$ en la población de ganado bovino del estado de Zacatecas, México. Esta se presenta principalmente en animales de la raza Criollo, machos, jóvenes, de doble propósito y en los municipios de mayor población bovina. Debido a los efectos negativos sobre la productividad del hato, es recomendable el análisis cromosómico como práctica rutinaria en la selección de los animales destinados a la reproducción, principalmente en los sementales, los cuales son importantes dada la relación hembra-macho que se maneja en el ganado bovino.

\section{LITERATURA CITADA}

1. Eldridge FE, Harris NB, Koenig JLF. Chromosomes of young AI bulls. VIth Eur Colt Cytogenet Domest Anim. Zurich, Suisse. 1984:59-67.

2. Graphodatsky AS, Trifonov VA, Stanyon R. The genome diversity and karyotype evolution of mammals. Mol Cytogenet 2011;4(1):22 doi:10.1186/1755-8166-4-22.

3. Gustavsson I, Rockborn G. Chromosome abnormality in three cases of lymphatic leukemia in cattle. Nature 1964;203(4948):990-991.

4. Basrur PK, Stranzinger G. Veterinary cytogenetics: past and perspective. Cytogenet Genome Res 2008;120(1-2):11-25.

5. Citek J, Rubes J, Hajkova J. Short communication: Robertsonian translocations, chimerism, and aneuploidy in cattle. J Dairy Sci 2009;92(7):3481-3483.
In intensive systems, carriers are more easily detected through records and continuous analysis of productive and reproductive parameters, which helps to minimize rob 1;29 prevalence $(8)$. In contrast, extensive systems use a small number of sires, natural mount reproduction, a larger number of cows and keep limited or no production and reproduction records. Consequently, the probability of rob $1 ; 29$ continuing in a population is much higher. Most Criollo breed populations in Colombia are found in extensive systems(20). The same is largely true of many herds in the municipalities of Zacatecas, where cattle are allowed to graze freely and no production records are kept(21).

In the state of Zacatecas, $39 \%$ of cattle belong to double-purpose systems, with $67 \%$ of individual animals are between one and three years of age, and the largest population being in Valparaíso municipality(22). This is why the categories productive purpose, age and municipality represented the highest probability of rob 1;29 prevalence; they were the categories with the most abundance. This suggests a generalized rob 1;29 presence in the state associated with low levels of technological management and insufficient herd records. The latter complicates identification of this translocation since it does not manifest phenotypically. Early diagnosis in sires and routine analysis in cows using karyotypic tests will help to generate the data needed to cull carrier animals, and reduce the impact on productive and reproductive indicators in cattle herds.

\section{CONCLUSIONS AND IMPLICATIONS}

Prevalence of the Robertsonian 1;29 translocation was $4.1 \%$ in cattle in the state of Zacatecas. It was identified mainly in the Criollo breed, males, young animals, double-purpose systems, and municipalities with the highest cattle population. Its negative impact on herd productivity highlights the need for routine chromosomal analysis of animals intended for 
6. Molteni L, Perucatti A, Lannuzzi A, Di Meo GP, De Lorenzi L, De Giovanni, A, Lannuzzi L. A new case of reciprocal translocation in a young bull: $\operatorname{rcp}(11 ; 21)(q 28 ; q 12)$. Cytogenet Genome Res 2007;116(1-2):80-84.

7. Bonnet-Garnier A, Lacaze S, Beckers JF, Berland HM, Pinton $A$, Yerle $M$, Ducos A. Meiotic segregation analysis in cows carrying the $\mathrm{t}(1 ; 29)$ Robertsonian translocation. Cytogenet Genome Res 2008;120(1-2):91-96.

8. Corredor CES, Jimenez RLM. Efecto de las anomalías cromosómicas sobre la fertilidad en bovinos. Orinoquia 2005;9(1):56-63.

9. Sánchez CA, Jiménez LM, Bueno M. Translocación Robertsoniana $(1 ; 29)$ en bovinos criollos colombianos. Rev Med Vet Zoot 2006;53(2):75-85.

10. Jiménez RLM. La citogenética en Medicina Veterinaria. Facultad de Medicina Veterinaria y de Zootecnia. Laboratorio de Citogenética. Universidad Nacional de Colombia, Sede Bogotá, 2000;13-120.

11. Lozano-Carbajal B, Meza-López C, De la Colina F, BañuelosValenzuela R, Báez JJ. Efecto de la poliploidia/aneuploidia linfocitaria sobre la fertilidad de vacas Holstein en el estado de Zacatecas, México. Abanico Vet 2013;3(3):22-29.

12. Lozano-Carbajal B, Márquez MC, Márquez A, Pérez JE. La translocación Robertsoniana 1/29 en vacas raza Suizo Pardo Americano y su repercusión en la reproducción. Vet Méx 1993;24(4):331-333.

13. R Core Team. R: A language and environment for statistical computing. Vienna, Austria: R Foundation for Statistical Computing; 2014.

14. Agresti A. An introduction to categorical data analysis. 2nd ed. Hoboken, New Jersey, USA: John Wiley and Sons, Inc.; 2007.

15. Venables WN, Ripley BD. Modern applied statistics with S. 4th ed. New York, USA: Springer; 2002. reproduction. Screening of sires is particularly important given the male:female ratio used in most cattle systems.

End of english version

16. Hervé M. RVAideMemoire: Diverse basic statistical and graphical functions, $\mathrm{R}$ package version 0.9-35 (Manual); 2014. http://cran.r-project.org/web/packages/ RVAideMemoire/index.html. Accesed Feb 12, 2015.

17. Vera O, Duraes MI, Medina R, Ocanto D. La translocación robertsoniana $1 / 29$ en bovinos criollos y mestizos venezolanos. Arch Zootec 2002;51(195):335-340.

18. Popescu CP, Pech A. Cattle $1 / 29$ translocation in the world (1964-1990): a review. Ann Zootech 1991;40(4):271-305.

19. Blazak WF, Eldridge FE. A Robertsonian translocation and its effect upon fertility in Brown Swiss cattle. J Dairy Sci 1977;60(7):1133-1142.

20. De Luca JC, Zufriategui L, Picco SJ, Ripoli MV, Giovambattista G, Rojas FV, Dulout FN. Incidence of 1/29 translocation in Bolivian Creole and Brahman Yacumeño cattle. Theriogenology 2002;58(7):1273-1281.

21. Chávez BC. Contribución al estudio de la ganadería bovina de carne: el caso de los distritos de Río Grande y Ojocaliente, Zacatecas, México. Investigación Científica 2008;4(3):1-17.

22. Instituto Nacional de Estadística y Geografía. Censo Agrícola, Ganadero y Forestal 2007. Tabulados-descarga. Zacatecas. Ganadería; 2007. http://www3.inegi.org.mx/sistemas/ tabuladosbasicos/default.aspx?c=17177\&s=est. Consultado Ene 13, 2015. 